\title{
Enumeration, identification and safety proprieties of lactic acid bacteria isolated from pork sausage
}

\author{
[Enumeração, identificação e propriedades de segurança de bactérias ácido- \\ lácticas isoladas de linguiça suína] \\ F.S. Dias $^{1}$, M.R.R.M. Santos ${ }^{2}$, R.F. Schwan ${ }^{2}$ \\ ${ }^{1}$ Universidade Federal do Vale do São Francisco - Petrolina, PE \\ ${ }^{2}$ Universidade Federal de Lavras - Lavras, MG
}

\begin{abstract}
Lactic Acid Bacteria (LAB) are indigenous microorganisms occurring in pork sausages. The utilization of selected autochthonous LAB may improve the safety of meat products. This study aims to enumerate and identify LAB in pork sausage and to characterize their safety properties, such as antimicrobial susceptibility and antibacterial activity. A total of 189 sealed packages of pork sausages were collected in seven municipalities (27 samples in each city) of Minas Gerais, Brazil. Microbiological analyses were performed to enumerate LAB. Two pre-selection criteria were applied to 567 isolates of LAB: catalase activity and tolerance to $\mathrm{pH} 2$. A total of 32 strains of UFLA SAU were selected, characterized phenotypically and identified through $16 \mathrm{~S}$ rDNA region sequencing. The susceptibility to antimicrobial and antibacterial activities of isolates was evaluated. The LAB count ranged from 3.079 to $8.987 \log _{10}$ CFU/g. Lactobacillus plantarum and Lactobacillus paracasei were identified in the samples. UFLA SAU 11, 20, 34, 86, 131 and 258 showed a profile of susceptibility to four antimicrobials: erythromycin, ampicillin, chloramphenicol and gentamycin. In the antibacterial activity test, with exception of UFLA SAU 1, all other strains showed efficiency in inhibiting Escherichia coli, Salmonella Typhi and Listeria monocytogenes. In the statistical analysis there was interaction among strains of Lactobacillus against the pathogens tested. L. monocytogenes $(P=0.05)$ was more sensitive to Lactobacillus strains and the highest inhibitory activity against this pathogen was achieved by strains UFLA SAU 135, 226, 238 and 258. Thus, UFLA SAU 11, 20, 34, 86, 131, 135, 226, 238 and 258 possess safety characteristics for application in meat products.
\end{abstract}

Keywords: sausages, Lactobacillus, susceptibility to antimicrobial, antibacterial activity

\section{RESUMO}

Bactérias ácido-lácticas (BAL) são microrganismos indígenas em linguiças. A utilização de selecionadas BAL autóctones pode melhorar a segurança dos produtos cárneos. Este estudo objetivou enumerar e identificar BAL em linguiças suínas e caracterizar suas propriedades de segurança, como a susceptibilidade antimicrobiana e a atividade antibacteriana. Um total de 189 embalagens fechadas de linguiça suína foi adquirido em sete municípios (27 amostras em cada cidade) de Minas Gerais, Brasil. Análises microbiológicas para a enumeração de BAL foram realizadas. Dois critérios de pré-seleção foram aplicados para os 567 isolados de BAL: atividade catalase e tolerância ao pH 2. Um total de 32 estirpes UFLA SAU foi selecionado, caracterizado fenotipicamente e identificado por meio do sequenciamento da região $16 S$ rDNA. A susceptibilidade a antimicrobianos e a atividade antimicrobiana dos isolados foram avaliadas. Nas linguiças, a contagem de BAL variou de 3,079 a 8,987 $\log _{10} \mathrm{UFC} / \mathrm{g}$. Lactobacillus plantarum $e$ Lactobacillus paracasei foram identificados nas amostras. UFLA SAU 11, 20, 34, 86, 131 e 258 apresentaram um perfil de suscetibilidade a quatro antimicrobianos: eritromicina, ampicilina, cloranfenicol e gentamicina. No teste de atividade antibacteriana, com exceção da UFLA SAU 1, todas as outras estirpes mostraram eficiência em inibir Escherichia coli, Salmonella Typhi e Listeria monocytogenes. Na análise estatística, houve interação entre estirpes de Lactobacillus contra os patógenos testados. L. monocytogenes $(P=0,05)$ foi mais sensível às estirpes de Lactobacillus, e a maior atividade inibitória contra este patógeno foi apresentada por estirpes

Recebido em 5 de fevereiro de 2015

Aceito em 17 de junho de 2015

E-mail: francesca.nobre@univasf.edu.br 
UFLA SAU 135, 226, 238 e 258. Assim, estirpes UFLA SAU 11, 20, 34, 86, 131, 135, 226, 238 e 258 possuem características de segurança para aplicação em produtos cárneos.

Palavras-chave: linguiças, Lactobacillus, susceptibilidade a antimicrobianos, atividade antibacteriana

\section{INTRODUCTION}

Brazil is the third largest producer and the fourth largest exporter of pork meat in the world. In the domestic market, the consumption of the product is concentrated in the industrialized products, especially sausages (ABIPECS, 2013). Pork sausage is a highly popular and appreciated pork product in Brazil, frequently consumed undercooked (Miyasaki et al., 2009). However, a challenge for the pork industry is the quality and safety of meat. This fact has been a public concern issue around the world (Tao et al., 2014).

Sausages are defined as products obtained from the animal meat butcher, with or without added fat tissues, ingredients, embedded in natural or artificial casing and submitted to a technical process (Brazil, 2000). Due to its composition, the sausage has a high microbiological risk. The product serves as substrate for several spoilage and pathogenic microorganisms (Cocolin et al., 2004). Furthermore, during the preparation of the sausage, the quality of the raw material, the $\mathrm{pH}$ and the absence of heat processing directly contribute to contamination and the multiplication of microorganisms (Sartz et al., 2008).

Therefore, due to the highly perishable nature of the product, several scientific studies in Brazil have reported the presence of pathogens, and particularly E. coli (Dias et al., 2011), Salmonella (Dias et al., 2013) and Listeria monocytogenes (Miyasaki et al., 2009). However, sausages are also a potential source of Lactic Acid Bacteria. Several publications have reported the identification of $\mathrm{LAB}$ in fresh meat and meat products (Ammor et al., 2005; Fontán et al., 2007a; Ducic et al., 2014). These microorganisms can be selected from the product. Selection of bacteria from sausage is advantageous because the microorganisms are adapted to the substrate (or matrix) and possess the appropriate physiological requirements for meat colonization (Pennacchia et al., 2004; Amor and Mayo, 2007).

LAB have certain characteristics that improve safety by inactivating pathogens, thereby improving product's stability and shelf-life through inhibiting the undesirable changes brought about by spoilage micro-organisms, and providing diversity by modifying the raw product to acquire new sensory properties (Lücke, 2000). Thus, the study of their safety properties becomes interesting, because these isolates may serve as an alternative in the product for inhibiting the presence of pathogens. In relation to safety criteria, it is also essential to analyze the profile of antimicrobial susceptibility of the strains.

This study aimed to enumerate and identify LAB in pork sausage and to characterize their safety properties, such as antimicrobial susceptibility and antibacterial activity.

\section{MATERIAL AND METHODS}

A total of 189 sealed packages of pork sausages (with a seal from the Federal Inspection Service) were collected from commercial establishments in the municipalities of Lavras, Varginha, Três Corações, São João Del Rei, Divinópolis, Betim and Belo Horizonte (Minas Gerais, Brazil). Twenty-seven samples were analyzed from each city. Samples were transported to the laboratory in isothermal boxes and analyzed immediately.

In the microbiological analysis for $\mathrm{LAB}, 10 \mathrm{~g}$ of each sausage sample was homogenized in $90 \mathrm{~mL}$ of $0.1 \%$ peptone, pH 7.00 (Difco Laboratories, Detroit, Mich.) in a Stomacher (Mayo Homogenius HG 400, Brazil). Decimal dilutions $\left(10^{-1}\right.$ to $\left.10^{-10}\right)$ were prepared and transferred to plates with a specific medium, de Man, Rogosa and Sharpe $\left(\mathrm{MRS}\right.$, Himedia $\left.{ }^{\circledR}\right)$ at $\mathrm{pH}$ 6.5. The plates were incubated at $30^{\circ} \mathrm{C}$ for 48 hours in aerobic conditions. Three isolates per sample were randomly selected from the MRS agar plates, reaching a total of 567 samples. Basic characterization of the isolates was performed through Gram reaction, morphology, motility, catalase $\left(\mathrm{H}_{2} \mathrm{O}_{2}, 3 \% \mathrm{vol} / \mathrm{vol}\right)$ and cytochromeoxidase activities.

Two pre-selection criteria were applied to the 567 isolates of LAB from pork sausage in Minas Gerais, Brazil. The first selection was by catalase activity in accordance with Ammor et al. (2005): 
101 strains possessed catalase activity. The second selection was based on the ability of the strains to tolerate pH 2 (Pennacchia et al., 2004). A total of 32 strains showed a high survival rate at this low $\mathrm{pH}$.

The API 50CH kit (BioMérieux) was used to identify, biochemically, the pre-selected 32 strains. The species names were confirmed using molecular identification. Bacterial DNA was extracted from each strain using a QIAamp DNA Mini Kit (Qiagen). The PCR reactions were carried out in a final volume of $50 \mu \mathrm{l}$ containing $25 \mu \mathrm{l}$ of TopTaq Master Mix (Qiagen), $1 \mu \mathrm{l}$ of each primer $(27 \mathrm{f} / 1512 \mathrm{r}), 2 \mu \mathrm{l}$ of DNA and $21 \mu \mathrm{l}$ of RNase free water (Wang et al., 2006). The unpurified PCR products were sequenced by Macrogen Inc. (Seoul, South Korea). Sequences were then compared with those in the GenBank database using the BLAST algorithm (National Centre for Biotechnology Information, Maryland, USA).

For antimicrobial susceptibility, the antimicrobials penicillin G (10UI/disc), nitrofurantoin $\quad(300 \mathrm{mg} / \mathrm{disc})$ teicoplanin (30 mg/disc), vancomycin $(30 \mathrm{mg} /$ disc), nalidixic acid (30mg/disc), chloramphenicol (30mg/disc), pipemidic acid (20mg/disc), erythromycin (15mg/disc), norfloxacin (10mg/disc), gentamicin (10mg/disc), ampicillin (10mg/disc), ciprofloxacin $(5 \mathrm{mg} / \mathrm{disc})$, ofloxacin $(5 \mathrm{mg} / \mathrm{disc})$, clindamycin ( $2 \mathrm{mg} / \mathrm{disc})$, and oxacillin ( $1 \mathrm{mg} / \mathrm{disc})$ were used, following the recommendations of the Clinical and Laboratory Standards Institute (CLSI, 2012). Lactobacillus isolates were grown on MRS agar for $24 \mathrm{~h}$ at $37{ }^{\circ} \mathrm{C}$, and then inoculated into $4 \mathrm{~mL}$ of sterile distilled water to achieve a 0.5 McFarland turbidity standard (Probac, São Paulo, Brazil). A swab was used to spread the inoculum across the surface of MullerHinton agar (Merck, Darmstadt, Germany), and then an antimicrobial disc (DME Polisensidisc 4 x 6, Specialized Diagnostic Microbiology, São Paulo, Brazil) was applied to the plate. Isolate resistance was assessed by measuring the inhibition zone of bacterial growth after incubation for $24 \mathrm{~h}$ at $37{ }^{\circ} \mathrm{C}$. Results were interpreted according to the cutoff levels proposed by Charteris et al. (1998).

The inhibitory effect of different strains of Lactobacillus over pathogens was tested using the agar disc diffusion method. Salmonella Typhi, Listeria monocytogenes and Escherichia coli were grown in Brain Heart Infusion agar (BHI, Merck) for $24 \mathrm{~h}$ at $37^{\circ} \mathrm{C}$. Each pathogen was suspended in $4 \mathrm{~mL}$ of sterile water and standardized to approximately $10^{8} \mathrm{CFU} / \mathrm{mL}$, compared to the standard turbidity $\mathrm{n}^{\circ} 0.5$ of McFarland. A sterile swab was soaked in the suspension and spread on the surface of a plate with BHI agar. After the inoculum was added and allowed to absorb, $6 \mathrm{~mm}$ sterile paper filter discs (Whatmann $n^{\circ} 1$ ), moistened with $20 \mu \mathrm{l}$ of cell free supernatant from each strain of Lactobacillus in the exponential growth phase were added. The supernatants were obtained by centrifugation $(2500 \times \mathrm{g} / 10 \mathrm{~min})$. The susceptibility of pathogens to the discs was assessed by measuring the zone of inhibition of bacterial growth around the discs (radius - mm) after incubation for $24 \mathrm{~h}$ at $37^{\circ} \mathrm{C}$. Each experiment was performed in triplicate. The data were analyzed using ANOVA, and the means were compared by a Scott-Knott test. Data were considered significantly different when the $P$ values were less than 0.05 . The statistical analysis was performed using SISVAR ${ }^{\circledR}$ (Lavras, Brazil) software, version 4.5.

\section{RESULTS AND DISCUSSION}

The enumeration of Lactic Acid Bacteria (LAB) in the samples analyzed is demonstrated in Table 1. In the sausages, $\mathrm{LAB}$ ranged from 3.079 to $8.987 \log _{10} \mathrm{CFU} / \mathrm{g}$. The average in municipalities remained between 6.124 and $7.735 \log _{10} \mathrm{CFU} / \mathrm{g}$. Our results for LAB counts are roughly one and two log-arithmic units lower than those reported by Fontán et al. (2007a) and Fontán et al. (2007b), respectively, and similar to those obtained by Ducic et al. (2014) in pork sausage starting the fermentation process (day zero). LAB are dominant groups in raw-cured sausages (Fontán et al., 2007a;b).

Thirty one strains were identified as Lactobacillus plantarum. Only strain UFLA SAU 130 was identified as Lactobacillus paracasei. The isolates identified by the API 50CHL test as the Lactobacillus plantarumgroup were identified with $99 \%$ of similarity by 16S rDNA sequencing as L. plantarum (Table 2). The strain UFLA SAU 130 was identified by the API 50CHL test as of the Lactobacillus caseigroup, and was confirmed by molecular identification as L. paracasei (HM462419.1) (Table 2). 
Table 1. Enumeration of LAB in 27 samples of pork sausage in each of the seven municipalities of Minas Gerais, Brazil

\begin{tabular}{|c|c|c|c|c|}
\hline \multirow[t]{2}{*}{ City } & \multicolumn{2}{|c|}{$\begin{array}{l}\text { Number of samples in the indicated } \\
\text { interval CFU/g }\left(\log _{10} \mathrm{CFU} / \mathrm{g}\right)\end{array}$} & \multirow{2}{*}{$\begin{array}{c}\text { Range } \\
\left(\log _{10} \mathrm{CFU} / \mathrm{g}\right)\end{array}$} & \multirow{2}{*}{$\begin{array}{c}\text { Average } \\
\left(\log _{10} \text { CFU/g }\right.\end{array}$} \\
\hline & $3,1-6$ & $6,1-9$ & & \\
\hline Lavras & 14 & 13 & $3.079-8.919$ & 6.124 \\
\hline Varginha & 2 & 25 & $5.531-8.964$ & 7.735 \\
\hline Três Corações & 5 & 22 & $3.079-8.987$ & 7.033 \\
\hline São João Del Rei & 4 & 23 & $5.079-7.924$ & 7.074 \\
\hline Divinópolis & 2 & 25 & $4.833-8.978$ & 7.678 \\
\hline Betim & 5 & 22 & $4.362-8.944$ & 7.422 \\
\hline Belo Horizonte & 5 & 22 & $3.415-8.839$ & 7.488 \\
\hline
\end{tabular}

Table 2. Identification by sequencing of part of $16 \mathrm{~S}$ rDNA of 32 strains of LAB isolated from fresh pork sausage

\begin{tabular}{|c|c|c|c|}
\hline $\begin{array}{c}\text { Strains } \\
\text { UFLA SAU }\end{array}$ & $\begin{array}{c}\text { Microorganism } \\
\text { Identified }\end{array}$ & $\begin{array}{l}\text { Percentage } \\
\text { Identity }(\%)\end{array}$ & $\begin{array}{c}\text { Gene bank } \\
\text { Accession Number }\end{array}$ \\
\hline 1 & Lactobacillus plantarum & 99 & HM562999.1 \\
\hline 11 & Lactobacillus plantarum & 99 & HM562999.1 \\
\hline 14 & Lactobacillus plantarum & 99 & EU419598.1 \\
\hline 18 & Lactobacillus plantarum & 99 & HM562999.1 \\
\hline 20 & Lactobacillus plantarum & 99 & AB510750.1 \\
\hline 34 & Lactobacillus plantarum & 99 & FJ227310.1 \\
\hline 52 & Lactobacillus plantarum & 99 & HM130542.1 \\
\hline 73 & Lactobacillus plantarum & 99 & HM130542.1 \\
\hline 86 & Lactobacillus plantarum & 99 & EU419598.1 \\
\hline 87 & Lactobacillus plantarum & 99 & HQ286594.1 \\
\hline 91 & Lactobacillus plantarum & 99 & HQ853454.1 \\
\hline 101 & Lactobacillus plantarum & 99 & EU419598.1 \\
\hline 125 & Lactobacillus plantarum & 99 & EU419598.1 \\
\hline 127 & Lactobacillus plantarum & 99 & AB510751.1 \\
\hline 130 & Lactobacillus paracasei & 99 & HM462419.1 \\
\hline 131 & Lactobacillus plantarum & 99 & FJ227315.1 \\
\hline 132 & Lactobacillus plantarum & 99 & EU419598.1 \\
\hline 135 & Lactobacillus plantarum & 99 & FJ538509.1 \\
\hline 145 & Lactobacillus plantarum & 99 & GU125615.1 \\
\hline 172 & Lactobacillus plantarum & 99 & GU644444.1 \\
\hline 185 & Lactobacillus plantarum & 99 & FJ763580.1 \\
\hline 186 & Lactobacillus plantarum & 99 & EU074830.1 \\
\hline 187 & Lactobacillus plantarum & 99 & EU074830.1 \\
\hline 204 & Lactobacillus plantarum & 99 & EU419598.1 \\
\hline 213 & Lactobacillus plantarum & 99 & HQ853454.1 \\
\hline 217 & Lactobacillus plantarum & 99 & HM130542.1 \\
\hline 220 & Lactobacillus plantarum & 99 & HM562999.1 \\
\hline 226 & Lactobacillus plantarum & 99 & EU419598.1 \\
\hline 238 & Lactobacillus plantarum & 99 & HM130542.1 \\
\hline 245 & Lactobacillus plantarum & 99 & FJ227315.1 \\
\hline 258 & Lactobacillus plantarum & 99 & AB510751.1 \\
\hline 265 & Lactobacillus plantarum & 99 & HQ853454.1 \\
\hline
\end{tabular}


In previous studies carried out on the species of LAB in sausage (Tran et al., 2011; Pennacchia et al., 2004), L. plantarum were found to be commonly associated with meat products as a natural inhabitant. Lactobacillus plantarum is a member of the facultatively heterofermentative group of lactobacilli. Some strains of $L$. plantarum produce bacteriocins (plantaricins) and possess the property of inhibiting Listeria monocytogenes (Lücke, 2000). Rantsiou et al. (2005) reported L. paracasei in sausages produced in Greece.

Lactobacillus plantarum and Lactobacillus paracasei have potential application for probiotic use in innovative starter cultures for meat products and are the species most commonly used as commercial meat LAB starter cultures (Amor and Mayo, 2007). For the meat industry the screening of indigenous LAB for fermentation products to standardize the biochemical properties in products, while using them to ensure safety, to maintain flavour and colour, and to shorten ripening time is extremely interesting. The indigenous $\mathrm{LAB}$, originating from fermented meats, are particularly well adapted to the ecology of meat fermentation and capable of dominating the microbiota of products (Lücke, 2000). In addition, the sausage matrix seems to act as a protection, improving the survival of probiotic lactobacilli through the gastrointestinal tract (Klingberg and Budde, 2006); thus, fermented meat products without heating could be suitable for assessing the use of probiotic LAB as starter cultures (Ammor and Mayo, 2007). Therefore, it is necessary to characterize the LAB isolated from the autochthonous fermented meat products in order to select the best strains (Ammor et al., 2005).

To select indigenous LAB as starter culture, the antimicrobial resistance pattern of the strain should be checked. The pattern of antimicrobial susceptibility of strains was low. For the 15 antimicrobials tested, 16 strains were susceptible to only one antibiotic $(6.66 \%)$, three strains to two $(13.33 \%)$, seven strains to three $(20 \%)$ and six strains to four antibiotics $(26.66 \%)$ (Table 3$)$.

The antimicrobial to which $94 \%$ of the strains were susceptible was erythromycin (Table 3). The same result was found by Cebecci and Gürakan (2003), and Ruiz-Moyano et al. (2009). Six strains (UFLA SAU 11, 20, 34, 86, 131, 258) showed the same profile to four antibiotics: sensitivity to erythromycin, ampicillin, chloramphenicol and gentamycin (Table 3).

LAB has a profile of intrinsic resistance to some antibiotics. For antimicrobial inhibitors of cell wall synthesis, all strains were resistant to oxicillin, penicillin $\mathrm{G}$, vancomycin and teicoplanin. Only $37.5 \%$ of strains were susceptible to ampicillin. LAB resistance has been described to oxacillin (Danielsen and Wind, 2003), peniclina G (Gevers et al., 2003), vancomycin (Danielsen and Wind, 2003; RuizMoyano et al. 2009), teicoplanin (Danielsen and Wind, 2003). Low resistance of lactobacilli to ampicillin was reported by Cebecci and Gürakan (2003).

For antimicrobial inhibitors of nucleic acid, all strains were resistant to norfloxacin, nalidixic acid, ofloxacin, pipemidic acid and ciprofloxacin. Cebecci and Gürakan (2003) reported resistance of $L$. plantarum to nalidixic acid and ofloxacin. According to Danielsen and Wind (2003) LAB exhibit natural resistance to norfloxacin and ciprofloxacin. Intrinsic resistance was recorded to pipemidic acid, reported by Mathur and Singh (2005).

Regarding susceptibility to inhibitors of protein synthesis, all strains were resistant to nitrofurantoin in agreement with Cebecci and Gürakan (2003). In this study, all strains were resistant to clindamycin. Lactobacillus are usually susceptible to this antimicrobial (Cebecci and Gürakan 2003; Charteris et al., 1998). For chloramphenicol, $59.4 \%$ of strains were resistant. According to Danielsen and Wind (2003), strains with transferable resistance genes present on the basis of their resistance to clindamycin and chloramphenicol. Only $37.5 \%$ of strains were susceptible to gentamicin, although Gevers et al. (2003) reported that $79 \%$ of Lactobacillus isolated from dry sausage were resistant to gentamicin.

The investigation of the resistance pattern of strains of Lactobacillus is important. According to Mathur and Singh (2005), the commercial introduction of probiotics containing antibiotic resistant strains may have negative consequences, because they are transferred to intestinal pathogens. On the other hand, as suggested by Charteris et al. (1998), the natural 
resistance of lactobacilli to a wide range of clinically important antibiotics may enable the development of antibiotic/probiotic combination therapies for conditions such as diarrhoea, female urogenital tract infection, and infective endocarditis.

Table 3. Antimicrobial susceptibility profiles ${ }^{\mathrm{a}}$ for Lactobacillus strains (\%) and susceptibility profiles (\%) for each antimicrobial

\begin{tabular}{|c|c|c|c|c|c|c|c|c|c|c|c|c|c|c|c|c|}
\hline Strains & $1^{b}$ & 2 & 3 & 4 & 5 & 6 & 7 & 8 & 9 & 10 & 11 & 12 & 13 & 14 & 15 & $\%$ \\
\hline 1 & $\mathrm{R}$ & $\mathrm{R}$ & $\mathrm{R}$ & $\mathrm{R}$ & $\mathrm{R}$ & $S$ & $\mathrm{R}$ & $\mathrm{R}$ & $\mathrm{R}$ & $\mathrm{R}$ & $\mathrm{R}$ & $\mathrm{R}$ & $\mathrm{R}$ & $\mathrm{R}$ & $\mathrm{R}$ & 6.66 \\
\hline 11 & $\mathrm{R}$ & $\mathrm{R}$ & $\mathrm{R}$ & $\mathrm{R}$ & $\mathrm{R}$ & $S$ & S & $\mathrm{S}$ & $S$ & $\mathrm{R}$ & $\mathrm{R}$ & $\mathrm{R}$ & $\mathrm{R}$ & $\mathrm{R}$ & $\mathrm{R}$ & 26.66 \\
\hline 14 & $\mathrm{R}$ & $\mathrm{R}$ & $\mathrm{R}$ & $\mathrm{R}$ & $\mathrm{R}$ & S & $\mathrm{R}$ & $\mathrm{R}$ & $\mathrm{R}$ & $\mathrm{R}$ & $\mathrm{R}$ & $\mathrm{R}$ & $\mathrm{R}$ & $\mathrm{R}$ & $\mathrm{R}$ & 6.66 \\
\hline 18 & $\mathrm{R}$ & $\mathrm{R}$ & $\mathrm{R}$ & $\mathrm{R}$ & $\mathrm{R}$ & $S$ & $\mathrm{R}$ & $\mathrm{R}$ & $\mathrm{R}$ & $\mathrm{R}$ & $\mathrm{R}$ & $\mathrm{R}$ & $\mathrm{R}$ & $\mathrm{R}$ & $\mathrm{R}$ & 6.66 \\
\hline 20 & $\mathrm{R}$ & $\mathrm{R}$ & $\mathrm{R}$ & $\mathrm{R}$ & $\mathrm{R}$ & $S$ & $S$ & $S$ & $S$ & $\mathrm{R}$ & $\mathrm{R}$ & $\mathrm{R}$ & $\mathrm{R}$ & $\mathrm{R}$ & $\mathrm{R}$ & 26.66 \\
\hline 34 & $\mathrm{R}$ & $\mathrm{R}$ & $\mathrm{R}$ & $\mathrm{R}$ & $\mathrm{R}$ & $\mathrm{S}$ & $S$ & $\mathrm{~S}$ & S & $\mathrm{R}$ & $\mathrm{R}$ & $\mathrm{R}$ & $\mathrm{R}$ & $\mathrm{R}$ & $\mathrm{R}$ & 26.66 \\
\hline 52 & $\mathrm{R}$ & $\mathrm{R}$ & $\mathrm{R}$ & $\mathrm{R}$ & $\mathrm{R}$ & $S$ & $\mathrm{R}$ & $\mathrm{R}$ & $\mathrm{R}$ & $\mathrm{R}$ & $\mathrm{R}$ & $\mathrm{R}$ & $\mathrm{R}$ & $\mathrm{R}$ & $\mathrm{R}$ & 6.66 \\
\hline 73 & $\mathrm{R}$ & $\mathrm{R}$ & $\mathrm{R}$ & $\mathrm{R}$ & $\mathrm{R}$ & $S$ & $\mathrm{R}$ & $\mathrm{R}$ & $\mathrm{R}$ & $\mathrm{R}$ & $\mathrm{R}$ & $\mathrm{R}$ & $\mathrm{R}$ & $\mathrm{R}$ & $\mathrm{R}$ & 6.66 \\
\hline 86 & $\mathrm{R}$ & $\mathrm{R}$ & $\mathrm{R}$ & $\mathrm{R}$ & $\mathrm{R}$ & $S$ & S & $S$ & $S$ & $\mathrm{R}$ & $\mathrm{R}$ & $\mathrm{R}$ & $\mathrm{R}$ & $\mathrm{R}$ & $\mathrm{R}$ & 26.66 \\
\hline 87 & $\mathrm{R}$ & $\mathrm{R}$ & $\mathrm{R}$ & $\mathrm{R}$ & $\mathrm{R}$ & $S$ & $\mathrm{R}$ & $\mathrm{R}$ & $\mathrm{R}$ & $\mathrm{R}$ & $\mathrm{R}$ & $\mathrm{R}$ & $\mathrm{R}$ & $\mathrm{R}$ & $\mathrm{R}$ & 6.66 \\
\hline 91 & $\mathrm{R}$ & $\mathrm{R}$ & $\mathrm{R}$ & $\mathrm{R}$ & $\mathrm{R}$ & $S$ & $\mathrm{R}$ & S & $\mathrm{R}$ & $\mathrm{R}$ & $\mathrm{R}$ & $\mathrm{R}$ & $\mathrm{R}$ & $\mathrm{R}$ & $\mathrm{R}$ & 13.33 \\
\hline 101 & $\mathrm{R}$ & $\mathrm{R}$ & $\mathrm{R}$ & $\mathrm{R}$ & $\mathrm{R}$ & S & $\mathrm{R}$ & $\mathrm{R}$ & $\mathrm{R}$ & $\mathrm{R}$ & $\mathrm{R}$ & $\mathrm{R}$ & $\mathrm{R}$ & $\mathrm{R}$ & $\mathrm{R}$ & 6.66 \\
\hline 125 & $\mathrm{R}$ & $\mathrm{R}$ & $\mathrm{R}$ & $\mathrm{R}$ & $\mathrm{R}$ & $S$ & $\mathrm{R}$ & $\mathrm{R}$ & $\mathrm{R}$ & $\mathrm{R}$ & $\mathrm{R}$ & $\mathrm{R}$ & $\mathrm{R}$ & MS & $\mathrm{R}$ & 6.66 \\
\hline 127 & $\mathrm{R}$ & $\mathrm{R}$ & $\mathrm{R}$ & $\mathrm{R}$ & $\mathrm{R}$ & S & $\mathrm{R}$ & $\mathrm{R}$ & $\mathrm{R}$ & $\mathrm{R}$ & $\mathrm{R}$ & $\mathrm{R}$ & $\mathrm{R}$ & $\mathrm{R}$ & $\mathrm{R}$ & 6.66 \\
\hline 130 & $\mathrm{R}$ & $\mathrm{R}$ & $\mathrm{R}$ & $\mathrm{R}$ & $\mathrm{R}$ & $S$ & $\mathrm{R}$ & $\mathrm{R}$ & $\mathrm{R}$ & $\mathrm{R}$ & $\mathrm{R}$ & $\mathrm{R}$ & $\mathrm{R}$ & $\mathrm{R}$ & $\mathrm{R}$ & 6.66 \\
\hline 131 & $\mathrm{R}$ & $\mathrm{R}$ & $\mathrm{R}$ & $\mathrm{R}$ & $\mathrm{R}$ & $S$ & S & $S$ & $S$ & $\mathrm{R}$ & $\mathrm{R}$ & $\mathrm{R}$ & $\mathrm{R}$ & $\mathrm{R}$ & $\mathrm{R}$ & 26.66 \\
\hline 132 & $\mathrm{R}$ & $\mathrm{R}$ & $\mathrm{R}$ & $\mathrm{R}$ & $\mathrm{R}$ & $S$ & $\mathrm{R}$ & $S$ & S & $\mathrm{R}$ & $\mathrm{R}$ & $\mathrm{R}$ & $\mathrm{R}$ & $\mathrm{R}$ & $\mathrm{R}$ & 20.00 \\
\hline 135 & $\mathrm{R}$ & $\mathrm{R}$ & $\mathrm{R}$ & $\mathrm{R}$ & $\mathrm{R}$ & $\mathrm{R}$ & S & S & $S$ & $\mathrm{R}$ & $\mathrm{R}$ & $\mathrm{R}$ & $\mathrm{R}$ & $\mathrm{R}$ & $\mathrm{R}$ & 20.00 \\
\hline 145 & $\mathrm{R}$ & $\mathrm{R}$ & $\mathrm{R}$ & $\mathrm{R}$ & $\mathrm{R}$ & $S$ & $S$ & $\mathrm{R}$ & $\mathrm{R}$ & $\mathrm{R}$ & $\mathrm{R}$ & $\mathrm{R}$ & $\mathrm{R}$ & $\mathrm{R}$ & $\mathrm{R}$ & 13.33 \\
\hline 172 & $\mathrm{R}$ & $\mathrm{R}$ & $\mathrm{R}$ & $\mathrm{R}$ & $\mathrm{R}$ & $S$ & $\mathrm{R}$ & $\mathrm{R}$ & $\mathrm{R}$ & $\mathrm{R}$ & $\mathrm{R}$ & $\mathrm{R}$ & $\mathrm{R}$ & $\mathrm{R}$ & $\mathrm{R}$ & 6.66 \\
\hline 185 & $\mathrm{R}$ & $\mathrm{R}$ & $\mathrm{R}$ & $\mathrm{R}$ & $\mathrm{R}$ & $S$ & $\mathrm{R}$ & $\mathrm{R}$ & $\mathrm{R}$ & $\mathrm{R}$ & $\mathrm{R}$ & $\mathrm{R}$ & $\mathrm{R}$ & $\mathrm{R}$ & $\mathrm{R}$ & 6.66 \\
\hline 186 & $\mathrm{R}$ & $\mathrm{R}$ & $\mathrm{R}$ & $\mathrm{R}$ & $\mathrm{R}$ & S & $\mathrm{R}$ & $\mathrm{R}$ & $\mathrm{R}$ & $\mathrm{R}$ & $\mathrm{R}$ & $\mathrm{R}$ & $\mathrm{R}$ & $\mathrm{R}$ & $\mathrm{R}$ & 6.66 \\
\hline 187 & $\mathrm{R}$ & $\mathrm{R}$ & $\mathrm{R}$ & $\mathrm{R}$ & $\mathrm{R}$ & S & $\mathrm{R}$ & $\mathrm{R}$ & $\mathrm{R}$ & $\mathrm{R}$ & $\mathrm{R}$ & $\mathrm{R}$ & $\mathrm{R}$ & $\mathrm{R}$ & $\mathrm{R}$ & 6.66 \\
\hline 204 & $\mathrm{R}$ & $\mathrm{R}$ & $\mathrm{R}$ & $\mathrm{R}$ & $\mathrm{R}$ & $S$ & $\mathrm{R}$ & $S$ & $S$ & $\mathrm{R}$ & $\mathrm{R}$ & $\mathrm{R}$ & $\mathrm{R}$ & $\mathrm{R}$ & $\mathrm{R}$ & 20.00 \\
\hline 213 & $\mathrm{R}$ & $\mathrm{R}$ & $\mathrm{R}$ & $\mathrm{R}$ & $\mathrm{R}$ & $S$ & $S$ & $S$ & $\mathrm{R}$ & $\mathrm{R}$ & $\mathrm{R}$ & $\mathrm{R}$ & $\mathrm{R}$ & $\mathrm{R}$ & $\mathrm{R}$ & 20.00 \\
\hline 217 & $\mathrm{R}$ & $\mathrm{R}$ & $\mathrm{R}$ & $\mathrm{R}$ & $\mathrm{R}$ & $S$ & $\mathrm{R}$ & $\mathrm{R}$ & $\mathrm{R}$ & $\mathrm{R}$ & $\mathrm{R}$ & $\mathrm{R}$ & $\mathrm{R}$ & $\mathrm{R}$ & $\mathrm{R}$ & 6.66 \\
\hline 220 & $\mathrm{R}$ & $\mathrm{R}$ & $\mathrm{R}$ & $\mathrm{R}$ & $\mathrm{R}$ & S & $\mathrm{S}$ & $\mathrm{S}$ & $\mathrm{R}$ & $\mathrm{R}$ & $\mathrm{R}$ & $\mathrm{R}$ & $\mathrm{R}$ & $\mathrm{R}$ & $\mathrm{R}$ & 20.00 \\
\hline 226 & $\mathrm{R}$ & $\mathrm{R}$ & $\mathrm{R}$ & $\mathrm{R}$ & $\mathrm{R}$ & $S$ & $\mathrm{~S}$ & $\mathrm{R}$ & $S$ & $\mathrm{R}$ & $\mathrm{R}$ & $\mathrm{R}$ & $\mathrm{R}$ & $\mathrm{R}$ & $\mathrm{R}$ & 20.00 \\
\hline 238 & $\mathrm{R}$ & $\mathrm{R}$ & $\mathrm{R}$ & $\mathrm{R}$ & $\mathrm{R}$ & S & $\mathrm{S}$ & $\mathrm{R}$ & $S$ & $\mathrm{R}$ & $\mathrm{R}$ & $\mathrm{R}$ & $\mathrm{R}$ & $\mathrm{R}$ & $\mathrm{R}$ & 20.00 \\
\hline 245 & $\mathrm{R}$ & $\mathrm{R}$ & $\mathrm{R}$ & $\mathrm{R}$ & $\mathrm{R}$ & $\mathrm{R}$ & $\mathrm{R}$ & $\mathrm{R}$ & $\mathrm{S}$ & $\mathrm{R}$ & $\mathrm{R}$ & $\mathrm{R}$ & $\mathrm{R}$ & $\mathrm{R}$ & $\mathrm{R}$ & 6.66 \\
\hline 258 & $\mathrm{R}$ & $\mathrm{R}$ & $\mathrm{R}$ & $\mathrm{R}$ & $\mathrm{R}$ & $S$ & $\mathrm{~S}$ & $\mathrm{~S}$ & $\mathrm{~S}$ & $\mathrm{R}$ & $\mathrm{R}$ & $\mathrm{R}$ & $\mathrm{R}$ & $\mathrm{R}$ & $\mathrm{R}$ & 26.66 \\
\hline 265 & $\mathrm{R}$ & $\mathrm{R}$ & $\mathrm{R}$ & $\mathrm{R}$ & $\mathrm{R}$ & $\mathrm{S}$ & $\mathrm{R}$ & $\mathrm{R}$ & $\mathrm{S}$ & $\mathrm{R}$ & $\mathrm{R}$ & $\mathrm{R}$ & $\mathrm{R}$ & $\mathrm{R}$ & $\mathrm{R}$ & 13.33 \\
\hline$\%$ & 0 & 0 & 0 & 0 & 0 & 94 & 37.5 & 37.5 & 40.6 & 0 & 0 & 0 & 0 & 0 & 0 & \\
\hline
\end{tabular}

${ }^{\mathrm{a}} \mathrm{R}$ : resistant, MS: moderately susceptible, S: susceptible.

${ }^{\mathrm{b}}$ 1-oxacillin, 2-penicillin G, 3-vancomycin, 4-teicoplanin, 5-clindamycin, 6-erythromycin, 7-ampicillin, 8gentamycin, 9-chloramphenicol, 10-norfloxacin, 11-acid nalidixic, 12-ofloxacin, 13-pipemidic acid, 14nitrofurantoin, 15-ciprofloxacin.

The Lactobacillus strains were examined for their antimicrobial activity against potentially pathogenic bacteria (Table 4). Since a clear zone of inhibition of at least $2 \mathrm{~mm}$ in diameter is considered to be positive (Ahmadova et al., 2013), in our study, except UFLA SAU 1, all other UFLA SAU strains showed efficiency in inhibiting E. coli, $S$. Typhi and $L$. monocytogenes. In the statistical analysis there was interaction among strains of Lactobacillus against the pathogens tested: L. monocytogenes $(P=0.05)$ was more sensitive to Lactobacillus strains, and the highest inhibitory activity against this pathogen was presented by strains UFLA SAU 135, 226, 238 and 258. No significant differences were found in the inhibitory activity of the UFLA SAU strains on $E$. coli and $S$. Typhi (average halo: $2.02 \mathrm{~mm}$ ) (Table 4). In accordance 
with Costa et al. (2013), the lactic acid is probably responsible for the inhibition of pathogen microorganisms. Ruiz-Moyano et al. (2009) reported that Lactobacillus strains do not inhibit Gram-negative bacteria; however, they showed moderate or high antimicrobial activity against strains of L. monocytogenes.

Table 4. Antibacterial activity of 32 strains of Lactobacillus against three pathogens, measured by agar disc diffusion (radius - mm) ${ }^{1}$

\begin{tabular}{|c|c|c|c|}
\hline Strains UFLA SAU & E. coli & $S$. Typhi & L. monocytogenes \\
\hline 1 & $0.67 \mathrm{aA}$ & $0.67 \mathrm{aA}$ & $2.00 \mathrm{aA}$ \\
\hline 11 & $1.33 \mathrm{aA}$ & $1.33 \mathrm{aA}$ & $3.33 \mathrm{aA}$ \\
\hline 14 & $3.00 \mathrm{aA}$ & $3.00 \mathrm{aA}$ & $1.33 \mathrm{aA}$ \\
\hline 18 & $2.33 \mathrm{aA}$ & $2.33 \mathrm{aA}$ & $4.33 \mathrm{bA}$ \\
\hline 20 & $4.00 \mathrm{aA}$ & $4.00 \mathrm{aA}$ & $5.00 \mathrm{bA}$ \\
\hline 34 & $3.00 \mathrm{a} \mathrm{A}$ & $3.00 \mathrm{aA}$ & $4.00 \mathrm{bA}$ \\
\hline 52 & $1.00 \mathrm{aA}$ & $1.00 \mathrm{aA}$ & $2.67 \mathrm{aA}$ \\
\hline 73 & $2.00 \mathrm{aA}$ & $2.00 \mathrm{aA}$ & $2.67 \mathrm{aA}$ \\
\hline 86 & $1.00 \mathrm{aA}$ & $1.00 \mathrm{aA}$ & $4.33 \mathrm{bB}$ \\
\hline 87 & $1.00 \mathrm{aA}$ & $1.00 \mathrm{aA}$ & $2.00 \mathrm{aA}$ \\
\hline 91 & $2.00 \mathrm{aA}$ & $2.00 \mathrm{aA}$ & $1.67 \mathrm{aA}$ \\
\hline 101 & $2.33 \mathrm{aA}$ & $2.33 \mathrm{aA}$ & $2.33 \mathrm{aA}$ \\
\hline 125 & $2.00 \mathrm{a} \mathrm{A}$ & $2.00 \mathrm{aA}$ & $4.00 \mathrm{bA}$ \\
\hline 127 & $2,33 \mathrm{aA}$ & $2.33 \mathrm{aA}$ & $1.33 \mathrm{aA}$ \\
\hline 130 & $1.67 \mathrm{aA}$ & $1.67 \mathrm{aA}$ & $4.33 \mathrm{bB}$ \\
\hline 131 & $2.00 \mathrm{a} \mathrm{A}$ & $2.00 \mathrm{aA}$ & $4.33 \mathrm{bB}$ \\
\hline 132 & $2.00 \mathrm{aA}$ & $2.00 \mathrm{aA}$ & $3.33 \mathrm{aA}$ \\
\hline 135 & $2.33 \mathrm{aA}$ & $2.33 \mathrm{aA}$ & $6.33 \mathrm{cB}$ \\
\hline 145 & $2.00 \mathrm{aA}$ & $2.00 \mathrm{aA}$ & $4.33 \mathrm{bB}$ \\
\hline 172 & $1.33 \mathrm{aA}$ & $1.33 \mathrm{aA}$ & $2.67 \mathrm{aA}$ \\
\hline 185 & $3.33 \mathrm{aA}$ & $3.33 \mathrm{aA}$ & $4.00 \mathrm{bA}$ \\
\hline 186 & $1.00 \mathrm{aA}$ & $1.00 \mathrm{aA}$ & $3.00 \mathrm{aA}$ \\
\hline 187 & $1.67 \mathrm{aA}$ & $1.67 \mathrm{aA}$ & $5.00 \mathrm{bB}$ \\
\hline 204 & $5.00 \mathrm{aA}$ & $5.00 \mathrm{aA}$ & $4.00 \mathrm{bA}$ \\
\hline 213 & $2.00 \mathrm{aA}$ & $2.00 \mathrm{aA}$ & $3.33 \mathrm{aA}$ \\
\hline 217 & $1.33 \mathrm{aA}$ & $1.33 \mathrm{aA}$ & $4.67 \mathrm{bB}$ \\
\hline 220 & $1.33 \mathrm{aA}$ & $1.33 \mathrm{aA}$ & $3.67 \mathrm{aB}$ \\
\hline 226 & $2.67 \mathrm{aA}$ & $2.67 \mathrm{aA}$ & $6.00 \mathrm{cB}$ \\
\hline 238 & $1.67 \mathrm{aA}$ & $1.67 \mathrm{aA}$ & $8.00 \mathrm{cB}$ \\
\hline 245 & $1.00 \mathrm{aA}$ & $1.00 \mathrm{aA}$ & $4.00 \mathrm{bB}$ \\
\hline 258 & $2.00 \mathrm{aA}$ & $2.00 \mathrm{aA}$ & $6.33 \mathrm{cB}$ \\
\hline 265 & $2.33 \mathrm{aA}$ & $2.33 \mathrm{aA}$ & $5.00 \mathrm{bB}$ \\
\hline Average Lactobacillus & $2.02 \mathrm{~A}$ & $2.02 \mathrm{~A}$ & $3.85 \mathrm{~B}$ \\
\hline
\end{tabular}

Mean values bearing the same superscript in upper (rows) or lower (columns) case letters are not significantly different $(P=0.05)$ according to the Scott- Knott test.

${ }^{1}$ Standard Error Mediam $($ SEM $)=0.83$ 
Listeria monocytogenes are a major problem for the meat industry, and although $\mathrm{NaNO}_{2}$ can inhibit Listeria and other pathogens in sausages, such substances may represent health risks for consumers, and there is a constant demand for new biopreservative agents. LAB originally isolated from traditional sausages is probably the best candidate for improving the microbiological safety of these foods, either by production of lactic acid or bacteriocin (Albano et al., 2007).

Another advantage in the inhibition of pathogens is that hydrogen peroxide is produced by LAB in the presence of oxygen as a result of the action of flavoprotein oxidases, or nicotinamide adenine dinucleotide (NADH) peroxidase. The antimicrobial effect of $\mathrm{H}_{2} \mathrm{O}_{2}$ may result from the oxidation of sulfhydryl groups causing denaturing of a number of enzymes, and from the peroxidation of membrane lipids, thus increasing membrane permeability. $\mathrm{H}_{2} \mathrm{O}_{2}$ may also act as a precursor for the production of bactericidal free radicals, such as superoxide $\left(\mathrm{O}^{-}\right)$and hydroxyl $\left(\mathrm{OH}^{\prime}\right)$ radicals, which can damage DNA (Ammor et al., 2006). From the technological perspective, hydrogen peroxide can interfere with the organoleptic properties of fermented meat products by increasing rancidity and the discoloration of the final product. Catalase hydrolyses hydrogen peroxide. The autochthonous starter cultures of UFLA SAU possess heme-dependent catalase activity, which is active in meat products since these substrates contain haemin in abundance (Ammor and Mayo, 2007).

\section{CONCLUSION}

Pork sausages are a potential source for isolating LAB. Lactobacillus plantarum and L. paracasei were identified in Brazilian pork sausage. UFLA SAU 11, 20, 34, 86, 131, 258 showed a profile of susceptibility to the four antimicrobials. UFLA SAU 135, 226, 238 and 258 presented with efficient action in inhibiting Listeria monocytogenes. Our findings reveal that UFLA SAU 11, 20, 34, 86, 131, 135, 226, 238 and 258 strains possess safety characteristics for potential application in meat products.

\section{ACKNOWLEDGMENT}

The authors wish to acknowledge $\mathrm{CNPq}$ (Conselho Nacional de Desenvolvimento Científico e Tecnológico) for scholarship and financial support.

\section{REFERENCES}

AHMADOVA, A.; TODOROV, S. D.; CHOISET, Y. et al. Evaluation of antimicrobial activity, probiotic properties and safety of wild strain Enterococcus faecium AQ71 isolated from Azerbaijani Motal cheese. Food Control, v.30, p.631-641, 2013.

ALBANO, H.; OLIVEIRA, M.; AROSO, R. et al. Antilisterial activity of lactic acid bacteria isolated from"Alheiras"(traditional Portuguese fermented sausages): In situ assays. Meat Sci., v.76, p.796-800, 2007.

AMMOR, S.; DUFOUR, E.; ZAGOREC, M. et al. Characterization and selection of Lactobacillus sakei strains isolated from traditional dry sausage for their potential use as starter cultures. Food Microbiol., v.22, p.529-538, 2005.

AMMOR, S.; TAUVERON, G.; DUFOUR, E. et al. Antibacterial activity of lactic acid bacteria against spoilage and pathogenic bacteria isolated from the same meat small-scale facility $1-$ Screening and characterization of the antibacterial compounds. Food Control, v.17, p.454-461, 2006.

AMMOR, M. S.; MAYO, B. Selection criteria for lactic acid bacteria to be used as functional starter cultures in dry sausage production: An update. Meat Sci., v.76, p.138-146, 2007.

BRASIL. Ministério da Agricultura Pecuária e Abastecimento. Instrução Normativa $\mathrm{N}^{\circ} 4$, de 31 de março de 2000. Regulamentos Técnicos de Identidade e Qualidade de Carne Mecanicamente Separada, de Mortadela, de Linguiça e de Salsicha. Diário Oficial da República Federativa do Brasil, Brasília-DF, Seção 1, p. 605 , abr. 2000.

CEBECI, A.; GÜRAKAN, C. Properties of potential probiotic Lactobacillus plantarum strains. Food Microbiol., v.20, n.5, p.511-518, 2003.

CHARTERIS, W. P.; KELLY, P. M.; MORELLI, L. et al. Antibiotic susceptibility of potentially probiotic Lactobacillus species. J. Food Prot., v.61, p.16361643, 1998.

COCOLIN, L.; RANTSIOU, K.; IACUMIN, L. et al. Study of the ecology of fresh sausages and characterization of populations of Lactic Acid Bacteria by molecular methods. Appl. Environ. Microbiol., v.70, p.1883-1894, 2004. 
COSTA, H.H.S.; SOUZA, M.R.; ACÚRCIO, L.B. et al. Potencial probiótico in vitro de bactérias ácidoláticas isoladas de queijo-de-minas artesanal da Serra da Canastra, MG. Arq. Bras Med. Vet. Zootec., v.65, p.1858-1866, 2013.

DANIELSEN, M.; WIND, A. Susceptibility of Lactobacillus spp. to antimicrobial agents. Int. J. Food Microbiol., v.82, p.1- 11, 2003.

DIAS, F.S.; ÁVILA, C.L.S.; SCHWAN, R.F. In situ inhibition of Escherichia coli isolated from fresh pork sausage by organic acids. J. Food Sci., v.76, p.M605M610, 2011.

DIAS, F.S.; RAMOS, C.L.; ÁVILA, A.R.A. et al. Identification of Salmonella isolated from pork sausage and evaluation of thermal and antimicrobial resistance of isolates. Afr. J. Microbiol. Res., v.7, p.5070-5075, 20013.

DUCIC, M.; BLAGOJEVIC, B.; MARKOV, S. et al. General patterns of background microbiota and selected bacterial pathogens during production of fermented sausages in Serbia. Food Control, v.43, p.231-237, 2014

FONTÁN, M.C.G.; LORENZO, J.M.; MARTÍNEZ, S. et al. characteristics of Botillo, a Spanish traditional pork sausage. LWT. J. Microbiol., v.40, p.1610-1622, 2007a.

FONTÁN, M.C.G.; LORENZO, J.M.; PARADA, A. et al. Microbiological characteristics of "androlla", a Spanish traditional pork sausage. Food Microbiol., v.24, p.52-58, 2007b.

GEVERS, D.; HUYS, G.; SWINGS, J. In vitro conjugal transfer of tetracycline resistance from Lactobacillus isolates to other Gram-positive bacteria. FEMS-Microbiol. Lett., v.225, p.125-130, 2003.

KLINGBERG, T.D.; BUDDE; B.B. The survival and persistence in the human gastrointestinal tract of five potential probiotic lactobacilli consumed as freezedried cultures or as probiotic sausage. Int. J. Food Microbiol., v.109, p.157-159, 2006.

LÜCKE, F.K. Utilization of microbes to process and preserve meat. Meat Sci., v.56, p.105-115, 2000.

MATHUR, S.; SINGH, R. Antibiotic resistance in food lactic acid bacteria-a review. Int. J. Food Microbiol., v. 105, p.281-295, 2005.
MIYASAKI, K.N.; CHIARINI, E.; SANTANA, A. de S. et al. High prevalence, low counts and uncommon serotypes of Listeria monocytogenes in linguiça, a Brazilian fresh pork sausage. Meat Sci., v.83, p.523527, 2009.

PENNACCHIA, C.; ERCOLINI, D.; BLAIOTTA, G. et al. Selection of Lactobacillus strains from fermented sausages for their potential use as probiotics. Meat Sci., v.67, p.309-317, 2004.

PERFORMANCE standards for antimicrobial susceptibility testing; twenty two informational supplement. Wayne, Pa.: CLSI, 2012. 188 p. (CLSI document M100-S22).

RANTSIOU, K.; DROSINOS, E.H.; GIALITAKI, M. et al. Molecular characterization of Lactobacillus species isolated from naturally fermented sausages produced in Greece, Hungary and Italy. Food Microbiol., v.22, p.19-28, 2005.

RELATÓRIO ABIPECS 2012. São Paulo: ABIPECS, 2013 Disponível em: <http://www.abipecs.org.br/ pt/relatorios.html>. Accessado em: 04 june 2014.

RUIZ-MOYANO, S.; MARTÍN, A.; BENITO, M. J. et al. Safety and functional aspects of pre-selected lactobacilli for probiotic use in Iberian dry-fermented sausages. Meat Sci., v.83, p.460-467, 2009.

SARTZ, L.; JONG, B.; HJERTQVIST, M. et al. An outbreak of Escherichia coli $0157: \mathrm{H} 7$ infection in southern Sweden associated with consumption of fermented sausage; aspects of sausage production that increase the risk of contamination. Epidemiol. Infect., v.136, p.370-380, 2008

TAO, F.; PENG, Y. A method for nondestructive prediction of pork meat quality and safety attributes by hyperspectral imaging technique. J. Food Eng., v.126, p.98-106, 2014.

TRAN, K.T.M.; MAY, B.K.; SMOOKER, P.M. et al. Distribution and genetic diversity of lactic acid bacteria from traditional fermented sausage. Food Res. Int., v.44, p.338-344, 2011

WANG, X.; HARUTA, S.; WANG, P. et al. Diversity stable enrichment culture which is useful for silage inoculant and its succession in alfalfa silage, FEM Microbiol. Lett., v.57, p.106-115, 2006. 